\title{
A NOTE ON THE USE OF THE SOUTH AFRICAN CLAWED TOAD IN THE BIOLOGICAL ASSAY OF THE DIGITALIS SERIES.
}

\author{
By J. W. C. GunN.
}

The clawed toad, Xenopus laevis, is the most common batrachian in laboratory use in South Africa. Morphologically it is most closely related to the toad, but it is active in its movements like the frog, and there is some evidence that its electrical responses are at least as quick as those of Rana.

Vulpian (1) was the first to state, and his observations have been repeatedly confirmed, that the European toad has a considerable degree of natural tolerance for poisons of the digitalis series, the minimal lethal dose for the toad being several times greater than for the frog. Abel and Macht (2) have shown the same to hold true for the tropical toad, Bufo agua.

It is therefore not only of scientific interest to determine whether Xenopus reacts to digitalis bodies like Bufo or Rana, but also of practical importance, since the most convenient method of standardising preparations of digitalis is to determine their toxicity for the frog.

\section{Method.}

The method employed was that in common use in biological assay of digitalis preparations. A measured quantity of the drug was made up to $\cdot 5$ c.c. with Ringer's solution and injected through the floor of the mouth into the ventral lymph-sac of the toad. Freshly caught animals were used. Either the minimal lethal dose or the amount required to arrest the ventricle in systole in one hour (the minimal systolic dose) was estimated.

The room temperature varied between $21^{\circ}$ and $23^{\circ} \mathrm{C}$.

\section{Minimal Lethal Dose of Strophanthin.}

The strophanthin used had been tested on Rana temporaria in the Wellcome Physiological Research Laboratories and the minimal lethal dose found to be about $0.0008 \mathrm{mgrm}$. per gramme weight of frog. 
Experiments on Xenopus laevis:

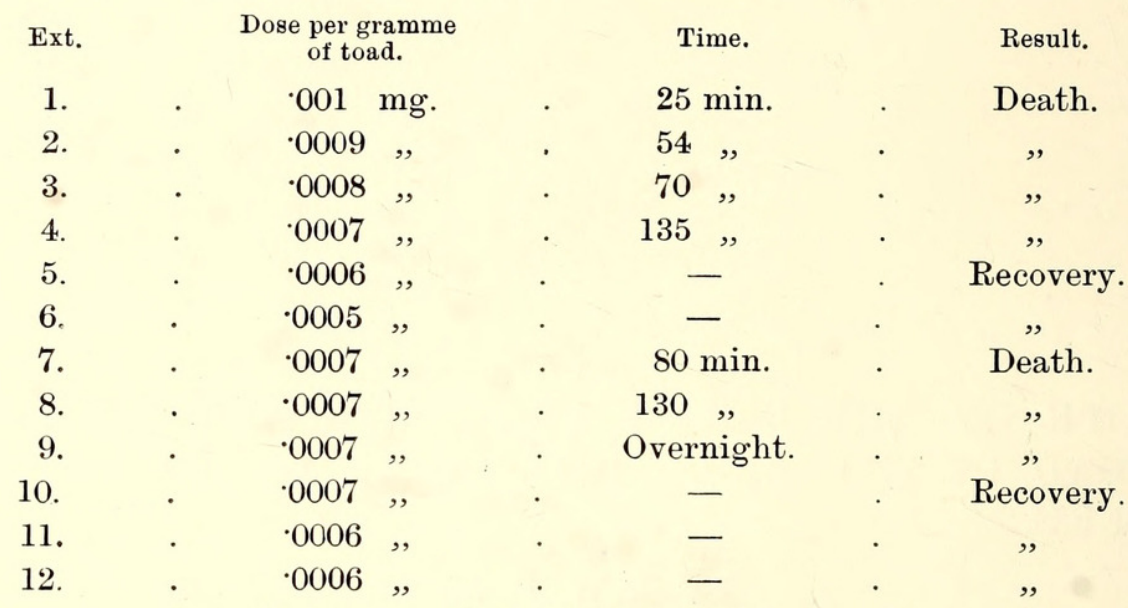

This would show that the minimal lethal dose of this strophanthin for the toad is $\cdot 0007 \mathrm{mgrm}$. per gramme, practically the same as for Rana temporaria.

\section{Minimal Systolic Dose of Tinctures (B.P.).}

Two freshly prepared tinctures of digitalis and one of squills were tested by the same method. At the end of one hour the toads were pithed and the condition of the heart examined. The tinctures were known to be active, in two cases by estimating the minimal lethal intravenous dose for cats, and in the other by subsequent clinical trial.

The minimal systolic doses of the tinctures of digitalis were 0055 c.c. and 005 c.c. per gramme of toad, and of the tincture of squills 006 c.c. per gramme. These figures are in close agreement with what would have been expected with Rana temporaria, in which an accepted standard of activity of these tinctures is a minimal systolic dose of 0.006 c.c. per gramme.

From these experiments it is concluded that Xenopus laevis is as susceptible as Rana to the action of the digitalis group, and that it may be used like Rana for the biological assay of digitalis preparations, the doses for both being the same.

\section{ReFERENCES.}

(1) Vulpian.- Compt. Rend. Soc. Biol.'’ ser. 2, i, 1854, p. 133.

(2) Aвel and Macht.- 'Journ. Pharm. Exper. Therap.,' iii, 1912, p. 319. 


\section{$2 \mathrm{BHL}$ Biodiversity Heritage Library}

Gunn, John William Cormack. 1922. "A NOTE ON THE USE OF THE SOUTH AFRICAN CLAWED TOAD IN THE BIOLOGICAL ASSAY OF THE DIGITALIS SERIES." Transactions of the Royal Society of South Africa 10, 55-56. https://doi.org/10.1080/00359192209519265.

View This Item Online: https://www.biodiversitylibrary.org/item/182861

DOI: https://doi.org/10.1080/00359192209519265

Permalink: https://www.biodiversitylibrary.org/partpdf/175626

\section{Holding Institution}

Smithsonian Libraries

\section{Sponsored by}

Biodiversity Heritage Library

\section{Copyright \& Reuse}

Copyright Status: Not in copyright. The BHL knows of no copyright restrictions on this item.

This document was created from content at the Biodiversity Heritage Library, the world's largest open access digital library for biodiversity literature and archives. Visit BHL at https://www.biodiversitylibrary.org. 